\title{
Medical Quiz: Single Best Answer (SBA)
}

\author{
Ahmed JU
}

(BIRDEM Med J 2018; 8(2): 188)

\section{Question No.01}

A 23-year-old man presents to the emergency with a 1day history ofsevere headache,discomfort when looking at the lights and neck stiffness. There isa non-blanching rash observed on his trunk. He has recently recovered fromchicken pox. On examination he is pyrexial at $39^{\circ} \mathrm{C}$. The most likely causativeorganism is:
A. Streptococcus pneumoniae
B. Listeria monocytogenes
C. Neisseria gonorrheae
D. Varicella Zoster
E. Neisseria menigitidis

Question No. 02

A 29-year-old man presents with a 4-week history of polyuria and extreme thirst. The patient denies difficulty in voiding, hesitancy or hematuria, although the urineis very dilute. The patient does not believe he has lost any weight and maintains agood diet. No findings are found on urine dipstick. The most appropriateinvestigation is:
A. Serum osmolality
B. Fasting plasma glucose
C. Urinary electrolytes
D. Magnetic resonance imaging (MRI) scan of the head
E. Water deprivation test

\section{Question No. 03}

A 32-year-old man presents to the emergency complaining ofback pain. This had started suddenly that morning after he had lifted a heavy boxat home. He mentions that the pain has been shooting down his left leg and hecannot walk without the support of his friend. $\mathrm{He}$ has not passed urine since theonset of pain. On neurological examination of the lower limbs, tone and powercannot be assessed due to pain but there are decreased ankle reflexes and a sacralanesthesia. What is the most appropriate next step?

\footnotetext{
Author Information

a. Dr. Jamal Uddin Ahmed, Associate Professor of Medicine, BIRDEM General Hospital
}

A. Give NSAID analgesia and complete neurological examination

B. Send the patient home with NSAID analgesia and bed rest advice

C. Arrange urgent MRI of spine

D. Give NSAID analgesia and catheterize the patient

E. Send the patient home with NSAID analgesia and advice to avoid heavylifting

Question No. 04

A 47-year-old woman presents complaining of dark stools and painful fingers onboth hands. She appears plethoric and complains of severe itching, often when sheis washing. She has hepatosplenomegaly. You have done red cell mass and erythropoietin levelsamong other tests. Which of the following is likely to be most accurate in thispatient?

A. Low erythropoietin and low red cell mass

B. Normal erythropoietin and normal red cell mass

C. Raised erythropoietin and low red cell mass

D. Raised erythropoietin and raised red cell mass

E. Low erythropoietin and raised red cell mass

\section{Question No. 05}

A 56-year-old man presents to you with a three-month history of weightloss despite no change in his appetite. The patient has no past medical history andno known drug allergies. Onexamination, you notice an area of hyperpigmentedskin in his left axilla. On palpation, thetexture of the area of hyperpigmentationfeels velvety. Which one of the followingmalignancies is most commonlyassociated with this dermatological presentation?
A. Lung carcinoma
B. Testicular carcinoma
C. Breast carcinoma
D. Gastrointestinal carcinoma
E. Prostate carcinoma 